\title{
EFFICACY OF GRANULOCYTE COLONY-STIMULATING FACTOR AND ENTEROSORPTION IN MELPHALAN-INDUCED BONE MARROW SUPPRESSION IN GUERIN CARCINOMA GRAFTED RATS
}

\author{
O.O. Shevchuk1*, I.M. Todor ${ }^{2}$, N.Yu. Lukianova², \\ N.K. Rodionova ${ }^{3}$, V.G. Nikolaev ${ }^{2}$, V.F. Chekhun ${ }^{2}$ \\ 1 - I. HORBACHEVSKY TERNOPIL NATIONAL MEDICAL UNIVERSITY, TERNOPIL, UKRAINE \\ 2 - R.E. KAVETSKY INSTITUTE OF EXPERIMENTAL PATHOLOGY, ONCOLOGY AND RADIOBIOLOGY \\ OF THE NATIONAL ACADEMY OF SCIENCES OF UKRAINE, KYIV, UKRAINE \\ 3 - INSTITUTE FOR NUCLEAR RESEARCH OF THE NATIONAL ACADEMY OF SCIENCES OF UKRAINE, \\ KYIV, UKRAINE
}

Background. Side effects of antineoplastic agents (especially leukopenia and neutropenia) could be the main limiting factors for efficient treatment.

Objective. The research is aimed at the study of myeloprotective capability of biosimilars of granulocyte colony stimulating factor (G-CSF) and granular carbon oral adsorbent C2 in melphalan-induced bone marrow suppression in Guerin carcinoma-grafted rats.

Methods. Melphalan at the dose of $5.5 \mathrm{mg} / \mathrm{kg}$ was used to promote bone marrow suppression in the Guerin carcinoma grafted rats. To fight myelosuppression, we used filgrastim and its analogue, designed and produced by IEPOR, a recombinant granulocyte colony-stimulating factor ( $r$-GCSF). Carbon granulated enterosorbent C2 was used for enteral sorption therapy (bulk density $y=0.18 \mathrm{~g} / \mathrm{cm}^{3}$, diameter of granules 0.15-0.25 mm, BET pore surface - $2162 \mathrm{~m}^{2} / \mathrm{g}$ ). All rats were sacrificed on the $17^{\text {th }}$ day after carcinoma cells inoculation or on the $8^{\text {th }}$ day after Melphalan injection.

Results. Alkylating cytostatic agent caused severe leukopenia (by 95.7\%), neutropenia (by 73.9\%), and thrombocytopenia (by $84.9 \%$ ) in the experimental rats. Mortality rate was 57\%. Filgrastim and enterosorption with carbon oral adsorbent C2 increased the studied indices, but the most prominent results were observed when combination of both factors was used. Studied means did not affect the anti-tumor efficacy of Melphalan alone and in combination.

Conclusions. Our results are perspective for further investigation of the efficacy of the combination of carbon oral adsorbents and hematopoietic cytokines in cases of ameliorate anti-cancer chemotherapy side effects, and its implementation into clinics.

KEY WORDS: melphalan; Guerin carcinoma; rats; granulocyte colony stimulating factor; enterosorption.

\section{Introduction}

Conventional dose-dense and dose-intense chemotherapy with radiation therapy and surgery promote significantly to the treatment of malignancies. Unfortunately, the side effects of antineoplastic agents are the main limiting factors for their efficiency [1-3]. The cells and tissues with high speed of division are the most sensitive. Bone marrow suppression, damage of gastrointestinal mucosa, gonadal toxicity, loss hair, dysfunctions and/or structural changes of kidney and liver are typical side effects of tumoricidal chemotherapy $[2,4,5]$. The

*Corresponding author: Shevchuk Oksana, 1 Maidan Voli, I. Horbachevsky Ternopil National Medical University, Ternopil, Ukraine 46001.

e-mail: shevchukoo@tdmu.edu.ua. incidence rates of myelotoxicity varies from 30 up to $60 \%$ [6]. The mortality rates due to febrile neutropenia among the patients undergoing chemotherapy are around $5-11 \%$ in adults and $2-6 \%$ in children $[7,8]$, and up to $20 \%$ in case of comorbidity [6]. So, amelioration of the negative effects and saving of the tumoricidal activity of chemotherapy are topical issues of contemporary oncology. Only complete courses of treatment may guarantee survival $[7,9]$.

Granulocyte colony-stimulating factor (G-CSF) and a granulocyte-macrophage colonystimulating factor (GM-CSF) are an irreplaceable part of supportive care in oncology and are used to reduce the incidence of severe leukopenia [10]. It has been proved in the cancer patients receiving multiple cycles of chemotherapy [11]. 
Endogenous intoxication is another component that makes the side effects of chemotherapy more severe. These syndrome compounds are the products of tumor metabolism, and the consequence of treatment (surgery, chemotherapy cause the damage of tumor tissues and increase in the quantity of toxic metabolites as well as its derivatives) [12]. Sorption Detoxification is a common and wellknown method for reducing toxic effects of chemotherapy [13-15]. Some of the main types, which are widely used in medicine today, are hemoperfusion (when blood is filtered through the column with activated carbon), enterosorption - enteral use of oral adsorbents of different types, and application-sorption therapy - use of carbon dressing for healing of burns and wounds.

Our previous experiments proved a significant bone marrow protection in melphalaninduced myelosuppression in the healthy rats $[16,17]$. But a topical issue of any additive supportive therapy in oncology is the impact on a tumor growth, not only the amelioration of anti-cancer chemotherapy side effects. So, the objective of our investigation is the study of myeloprotective capability of biosimilars of granulocyte colony stimulating factor (G-CSF) and enteral sorption therapy with carbon oral adsorbent C2 in Melphalan-induced bone marrow suppression in the Guerin carcinoma grafted rats.

\section{Methods}

Melphalan (Alkeran, GlaxoSmithKline, UK) was used to promote the bone marrow suppression. Carbon granulated enterosorbent C2 (produced by R.E. Kavetsky Institute of Experimental Pathology, Oncology and Radiobiology, IEPOR) was used for enteral sorption therapy. The parameters of enterosorbent C2 are: bulk density $\mathrm{y}=0.18 \mathrm{~g} / \mathrm{cm}^{3}$, diameter of granules 0.15-0.25 mm, BET pore surface $-2162 \mathrm{~m}^{2} / \mathrm{g}$. Filgrastim (Neupogen, Hoffman La Roche) and G-CSF-analogue of IEPOR production - recombinant granulocyte colony-stimulating factor ( $r$-GCSF) were used to increase the white blood cell (WBC) count. $r$-GCSF was designed within the State Grant No. 487/2011 from 29.09.2011 "Development of technology for synthesis of human recombinant granulocyte colony stimulating factor and medication on its basis".

The experiments were performed using mature Wistar female rats, $200 \pm 20 \mathrm{~g}$ of body mass, which were got from the vivarium of IEPOR (Kyiv, Ukraine). Guerin carcinoma cells were taken from the Bank of Cell Lines from Human and Animal Tissues of the abovementioned institute. All procedures were performed according to the rules and requirements of European Convention for the Protection of Vertebrate Animals Used for Experimental and Other Scientific Purposes and a local Ethic Committee of IEPOR. The tumors were implanted by subcutaneous injection (dorsally into the left flank) of $2.2 \times 10^{6}$ Guerin carcinoma cells suspended in $0.5 \mathrm{ml}$ of sterile physiological solution. All animals were randomly divided into 6 groups $(n=7)$. The $1^{\text {st }}$ group was a tumor control group. All rats of groups 2-6 were administered with Melphalan: the $3^{\text {rd }}$ group involved the rats, which were administered with filgrastim injections (Melphalan + filgrastim) in addition to the cytostatic agent; the $4^{\text {th }}$ - enteral sorption therapy with C2 (Melphalan + C2), the $5^{\text {th }}$ group - the rats, which were administered with both agents (Melphalan + filgrastim + C2), and the $6^{\text {th }}$ group - the animals, which received r-CSF and carbon oral adsorbents C2 (Melphalan + $r-C S F+C 2)$.

On the $10^{\text {th }}$ day after Guerin carcinoma grafting, Melphalan was injected intravenously (into the tail vein) one time at the dose of $5.5 \mathrm{mg} / \mathrm{kg}$ to the rats of groups 2-6. Beginning from the following day and for four next days, filgrastim or $r$-CSF was injected subcutaneously at the dose of $50 \mathrm{mcg} / \mathrm{kg}$. A suspension of carbon enterosorbent (C2 dosage of $5 \mathrm{ml} / \mathrm{kg}$ of animals' body weight, or $900 \mathrm{mg}$ of dry mass of enterosorbent) in appropriate quantity of distilled water was introduced via the tube into rat stomach during 3 days before the Melphalan injection and during 7 days after it (once a day).

The rats' mortality rate and dynamics of tumor growth was studied as well. The rats were weighted, and blood was taken from the heart under Ketamine hydrochloride general anesthesia on the $8^{\text {th }}$ day after Melphalan injection (the $17^{\text {th }}$ day after Guerin carcinoma cells inoculation). Automatic hematology analyzer Particle Counter E120 (Erma Inc., Japan) was used for evaluation of complete blood cell count.

Statistical analysis. Since data were not normally distributed in all groups (Shapiro-Wilk Normality Test), non-parametric tests (MannWhitney U-test and one-way ANOVA test) were used in data analysis (statistical significance at $p<0.05)$. The data were expressed as the mean \pm standard error of the mean ( $\mathrm{M} \pm \mathrm{SE})$. All statistical calculations were performed using the Origin 7.5 Software (OriginLab Corporation, USA). 


\section{Results}

All rats survived in the tumor control group on the $17^{\text {th }}$ day after Guerin carcinoma cells inoculation, while Melphalan injection caused the death of 4 rats (the $2^{\text {nd }}$ group). In the group of rats, which received carbon oral adsorbent, 2 rats died. In all other groups one rat died in each group till the end of experiment (Figure 1). So, we evidenced the mortality rate of $57.1 \%$ in the Melphalan group, while the combination of both agents of correction (G-CSF and carbon oral adsorbent) reduced this number to $14.3 \%$.

It was established that a single injection of cytostatic agent Melphalan caused significant leukopenia from $(13.9 \pm 1.9)$ to $(0.6 \pm 0.1) \times 10^{9} / \mathrm{L}$ (Figure 2). The decreasing of WBC count by $95.7 \%$ explained a high mortality rate in the Melphalan group (the $2^{\text {nd }}$ group). Course of
Filgrastim promoted 2.3-fold increase of WBC count (or by $133.3 \%$ ) compare to the Melphalan group. Enteral sorption therapy also increased this index in 1.5 times (or by $50.0 \%$ ). The use of combination of both G-CSF drugs and enterosorbent had the tendency to be more effective compare to the administration of each drug alone. The WBC count increased in 2.8 times (or by $183.3 \%$ ) in the Melphalan+filgrastim $+\mathrm{C} 2$ group and in 2.7 times (or by $166.7 \%$ ) in the Melphalan+r-GCSF+C2 group compare to the Melphalan group.

As for the WBC formula, the results of the experiment are presented in Figure 3.

Single Melphalan injection at the dose of $5.5 \mathrm{mg} / \mathrm{kg}^{-1}$ significantly decreased the granulocytes percentage in the peripheral blood by $73.9 \%$, monocytes were absent at all. The

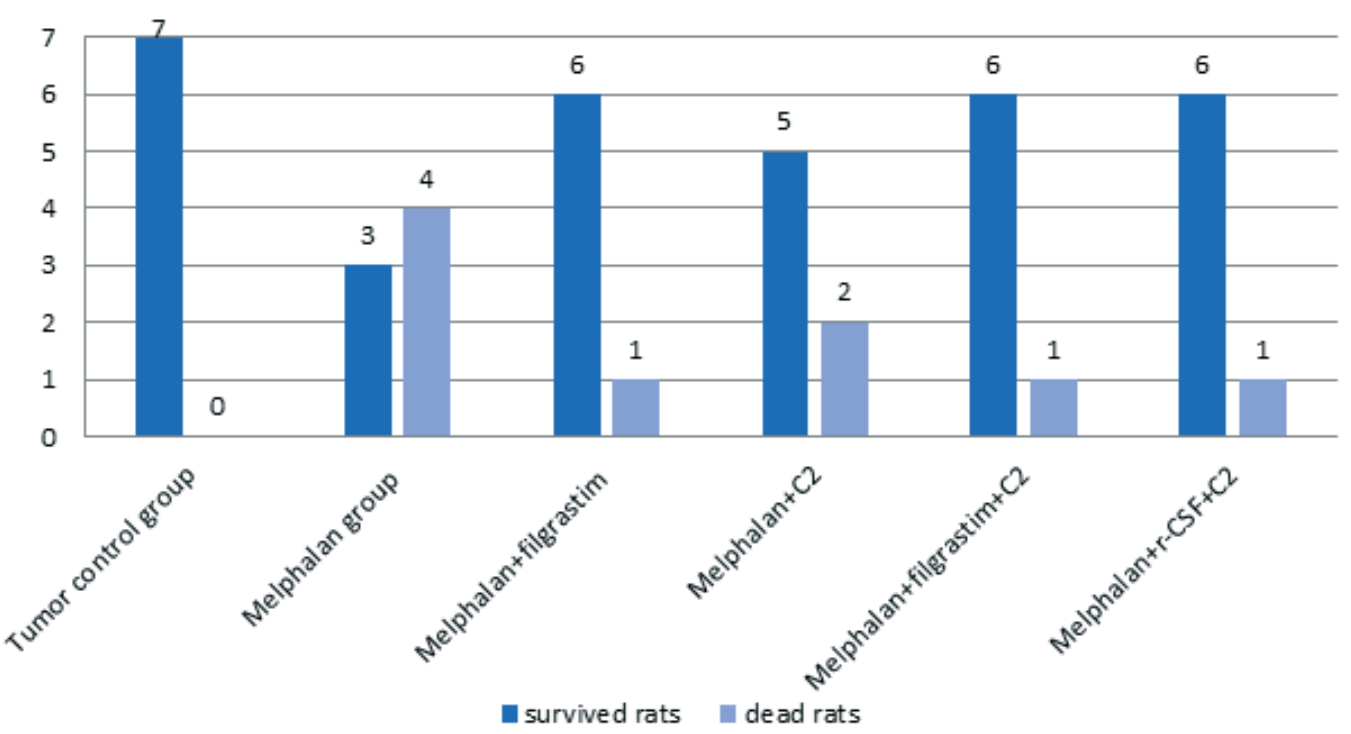

Figure 1. Survival and mortality rates among the Guerin carcinoma grafted rats, which received Melphalan, biosimilars of G-CSF and enterosorbent C2 on the $17^{\text {th }}$ day after tumor cells inoculation.

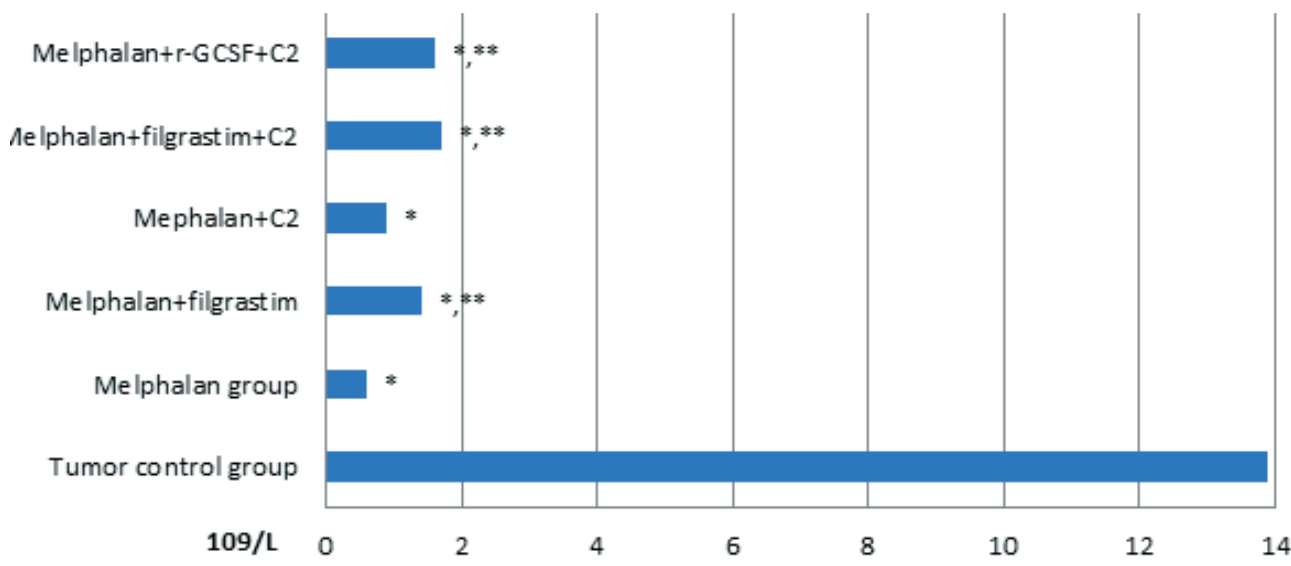

Figure 2. White blood cell (WBC) count in the Guerin carcinoma grafted rats, which received Melphalan, biosimilars of G-CSF and enterosorbent $\mathrm{C} 2$ on the $17^{\text {th }}$ day after tumor cells inoculation. Notes: * - $p<0.05$ compare to the tumor control group; ** $-p<0.05$ compare to the Melphalan group. 


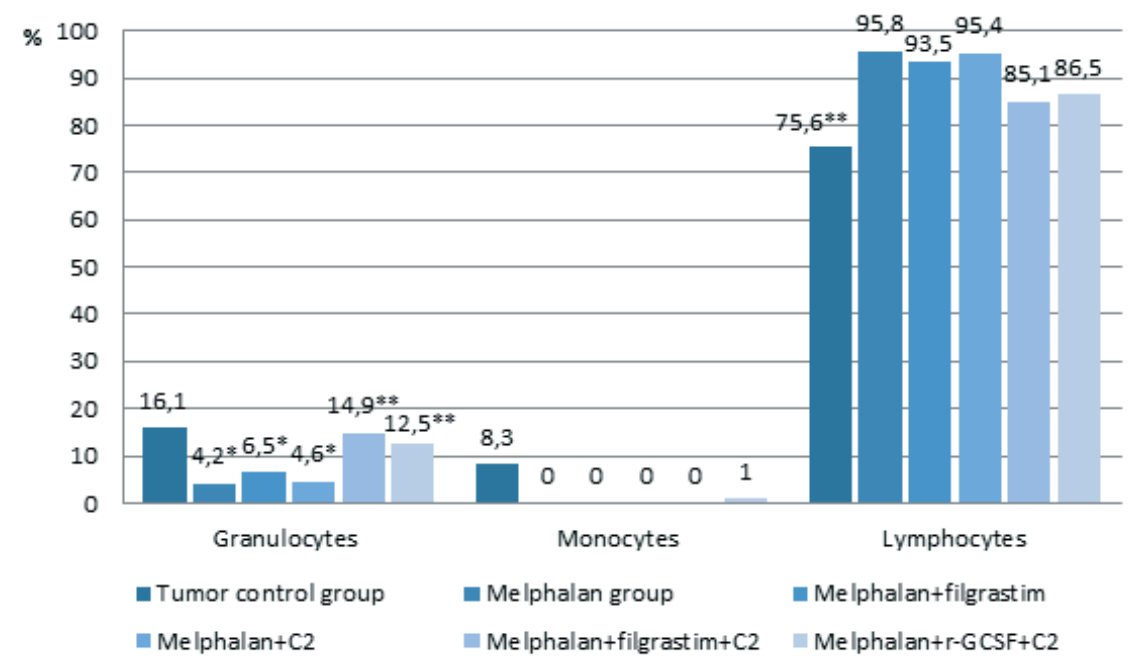

Figure 3. White blood cell (WBC) formula of the peripheral blood in Guerin carcinoma grafted rats, which received Melphalan, biosimilars of G-CSF and enterosorbent C2 on the $17^{\text {th }}$ day after tumor cells inoculation. Notes: * $-p<0.05$ compare to the tumor control group; ** $-p<0.05$ compare to the Melphalan group.

increased number of lymphocytes in the peripheral blood was evidenced that can be explained by critically low WBC count and violation of cells composition. The administration of filgrastim and carbon oral adsorbent C2 alone did not influence significantly; a slight tendency of increase of the indices was evidenced. The combination of both factors led to normalization of granulocytes percentage in the peripheral blood, while the number of leukocytes was still quite low (Figure 2). So, granulocytes number increased by $254.8 \%$ (in 3.6 times) in the the Melphalan+filgrastim $+\mathrm{C} 2$ group and by $197.6 \%$ (approximately in 3 times) in the Melphalan+r-GCSF+C2 group compare to the Melphalan group.

As for the red blood cell (RBC) count and hemoglobin, no significant impact of any drug used in the experiment was evidenced. But a 6.6 -fold decrease of platelets count was observed in the rats (or by $84.9 \%$ ), which were administered with Melphalan compare to the tumor control group (Table 1).
The same tendency as for the granulocytes percentage was evidenced concerning the platelets count: only the tendency for amelioration of low platelets level. The combination of both drugs: officinal filgrastim or specially designed analogue r-GCSF together with carbon oral adsorbent $\mathrm{C} 2$, caused significant increase of thrombocytes number in peripheral blood. Thus, platelets count increased in 4.2 times (or by $319.6 \%$ ) in the Melphalan+filgrastim+C2 group, and approximately in 3 times (or by $198 \%$ ) in the Melphalan+r-GCSF+C2 group compare to the $2^{\text {nd }}$ Melphalan group.

The tumor growth dynamics in case of the administration of alkylating cytostatic agent and G-CSF analogues as well as enterosorption was a significant aim of the study. Melphalan was injected on the $10^{\text {th }}$ day after Guerin carcinoma cells inoculation, when a tumor was formed (Table 2). On the $17^{\text {th }}$ day of the experiment a significant slow of tumor growth compare to the tumor control group was evidenced. There was no negative effect of

Table 1. RBC and platelets count as well as hemoglobin level in peripheral blood in the Guerin-carcinoma grafted rats in case of Melpahaln, G-CSF-analogues and enteral sorption therapy, $\mathrm{M} \pm \mathrm{SE}$

\begin{tabular}{|l|c|c|c|}
\hline \multicolumn{1}{|c|}{ Indices } & $\begin{array}{c}\text { RBC count, } \\
\times 10^{12} / \mathrm{L}\end{array}$ & $\begin{array}{c}\text { Platelets count, } \\
\times 10^{9} / \mathrm{L}\end{array}$ & $\mathrm{Hb}, \mathrm{g} / \mathrm{L}$ \\
\hline Tumor control group, $(\mathrm{n}=7)$ & $7.73 \pm 0.51$ & $325.6 \pm 35.9 * *$ & $152.0 \pm 8.0$ \\
\hline Melphalan group, $(\mathrm{n}=3)$ & $8.70 \pm 2.65$ & $49.0 \pm 11.9 *$ & $130.0 \pm 30.0$ \\
\hline Melphalan + filgrastim group, $(\mathrm{n}=6)$ & $10.57 \pm 1.19$ & $74.0 \pm 9.5^{*}$ & $211.0 \pm 25.0$ \\
\hline Melphalan + C2 group, $(\mathrm{n}=5)$ & $8.06 \pm 0.68$ & $60.0 \pm 8.6^{*}$ & $153.0 \pm 15.0$ \\
\hline Melphalan + filgrastim + C2 group, $(\mathrm{n}=6)$ & $10.21 \pm 1.00$ & $205.6 \pm 86.2 * *$ & $188.0 \pm 18.0$ \\
\hline Melphalan + r-GCSF + C2 group, $(\mathrm{n}=6)$ & $7.91 \pm 0.81$ & $146.0 \pm 36.8^{*}, * *$ & $146.0 \pm 17.0$ \\
\hline
\end{tabular}

Notes: $*-p<0.05$ compare to the tumor control group; ** $-p<0.05$ compare to the Melphalan group. 
Table 2. Dynamics of the Guerin carcinoma growth in the experimental groups (volume, $\mathrm{cm}^{3}, \mathrm{M} \pm \mathrm{SE}, \mathrm{n}=7$ )

\begin{tabular}{|l|c|c|}
\hline \multirow{2}{*}{\multicolumn{1}{|c|}{ Group }} & \multicolumn{2}{c|}{ Day after tumor's inoculation } \\
\cline { 2 - 3 } & $10^{\text {th }}$ day & $17^{\text {th }}$ day \\
\hline Tumor control group & $3.7 \pm 0.2$ & $11.3 \pm 0.2$ \\
\hline Melphalan group & $3.8 \pm 0.3$ & $6.6 \pm 0.2$ * \\
\hline Melphalan + filgrastim group & $3.7 \pm 0.2$ & $6.4 \pm 0.3 *$ \\
\hline Melphalan + C2 group & $3.5 \pm 0.2$ & $6.1 \pm 0.2 *$ \\
\hline Melphalan + filgrastim + C2 group & $3.8 \pm 0.3$ & $6.0 \pm 0.4 *$ \\
\hline Melphalan + r-GCSF + C2 group & $3.7 \pm 0.4$ & $6.0 \pm 0.3 *$ \\
\hline
\end{tabular}

Notes: * $-p<0.05$ compare to the tumor control group.

G-CSF drugs or enterosorbent C2 on the anticancer action of Melphalan. On the $17^{\text {th }}$ day the tumors sizes decreased by $41.6 \%$ in the Melphalan group, by $43.4 \%$ in the Melphalan+ filgrastim group, by $46.0 \%$ in the Melphalan+C2 group, and by $46.9 \%$ in the groups of rats, which received combination of enterosorption and hematostimulating cytokines. We assessed the tumors size in all groups of rats.

\section{Discussion}

Typical side effects of anti-cancer chemotherapy, and leukopenia as the most common among them, are tightly related to the clinical outcomes $[1,18]$. More and more attention is paid to this issue, especially after the success of modern techniques such as a stem cell transplantation and cytokines treatment to restore hematopoietic functions. Different chemotherapy regimens are classified to develop a high risk (more than $20 \%$ ), an intermediate risk (from 10 to $20 \%$ ) or a low risk (less than $10 \%$ ) of febrile neutropenia [6]. All of them require administration of different doses of hematopoietic cytokines to prevent and treat complication of tumoricidal therapy. G-CSF influences cellular proliferation, differentiation, maturation, and lineage commitment in the bone marrow not only of neutrophils but of shortterm hematopoietic stem cells, colony forming units granulocyte erythroid macrophage megakaryocyte, colony-forming units granulocyte macrophage and colony forming units granulocyte as well [19]. The American Society of Clinical Oncology (ASCO) recommends primary prophylaxis with G-CSF or GM-CSF for the expected incidence of neutropenia of $\geq 40 \%$ [20]. Also, pegfilgrastim (sustained duration form of filgrastim, G-CSF) is recommended for administration for at least 1 day after chemotherapy [21].

G-CSF drugs are mostly well tolerated. One of the most common reported side effects is bone pain (which is not treatment-limiting), neutrophilic dermatoses, exacerbation of psoriasis and isolated anaphylactic reactions as well as coagulation abnormalities also may appear. Transient renal and biological disturbances are reported $[22,23]$. Dyspnea, pain in chest and hypoxemia, nausea, diaphoresis, anaphylactic reactions, syncope and flushing are evidenced [24]. Unfortunately, G-CSF is helpless to fight other than leukopenia side effects [25]. Also, it does not penetrate through the alveolar barrier and cannot prevent lung injury, especially during the concomitant radiation therapy [26]. So, it means we may enhance the efficacy of G-CSF therapy in the patients with malignancies during chemotherapy courses and Sorption Detoxification is a promising issue. First positive results for myeloprotective effect of enterosorption were published in 1980-90 th [15]. Since that time there are a lot of evidences for successful use of enterosorption in oncology practice $[12,13$, 27-29]. Our previous experiments in healthy rats demonstrated advantages of combination of G-CSF and enterosorption to ameliorate side effects of melphalan and cisplatin $[16,30]$. This study has proved that such combination has no negative impact on tumoricidal activity of alkylating cytostatic agent Melphalan and promotes animals' survival: mortality rate decreased from 57 to $14 \%$.

\section{Conclusions}

The side effects of anti-cancer drugs, espe cially bone marrow suppression and neutro_ penia, are the main limiting factors for full courses of chemotherapy, which is crucial for treatment efficacy.

Melphalan at single injection at the dose of $5.5 \mathrm{mg} / \mathrm{kg}$ caused significant leukopenia and granulocytopenia in the Guerin carcinoma grafted rats. Mortality rate was $57.1 \%$. The filgrastim (recombinant granulocyte colony 
stimulating factor) or enteral sorption therapy with carbon oral adsorbent C2 (bulk density $\mathrm{y}=0.18 \mathrm{~g} / \mathrm{cm}^{3}$, diameter of granules 0.15 $0.25 \mathrm{~mm}$, BET pore surface $-2162 \mathrm{~m}^{2} / \mathrm{g}$ ) for correction of melphalan-induced myelosuppression increased white blood cell count, but the most prominent results were evidenced only when combination of both factors was used, especially regarding the granulocytes number. Also, only in the group of rats, which received both Filgrastim or r-GCSF, produced by IEPOR, and enterosorption, the restoration of platelets count was observed. The use of both factors of correction did not ameliorate the anti-tumor efficacy of alkylating cytostatic agent.

Thus, the results are perspective for further study of the use of combination of carbon oral adsorbents and hematopoietic cytokines to ameliorate anti-cancer chemotherapy side effects, as well as their implementation into clinical practice.

\section{Conflicts of Interest}

Authors declare no conflict of interest.

\title{
ЕФЕКТИВНІСТЬ ЗАСТОСУВАННЯ ПРЕПАРАТІВ ГРАНУЛОЦИТАРНОГО КОЛОНІЕСТИМУЛЮЮЧОГО ФАКТОРУ ТА ЕНТЕРОСОРБЦЇ ПРИ МЕЛФАЛАН-ІНДУКОВАНІЙ МІЄЛОСУПРЕСІЇ У ЩУРІВ 3 ПЕРЕВИВНОЮ КАРЦИНОМОЮ ГЕРЕНА
}

\author{
О.О. Шевчук' , І.М. Тодор², Н.Ю. Лук'янова², \\ Н.К. Родіонова ${ }^{3}$, В.Г. Ніколаєв ${ }^{2}$, В.Ф. Чехун ${ }^{2}$ \\ 1 - ТЕРНОПІЛЬСЬКИЙ НАЦІОНАЛЬНИЙ МЕДИЧНИЙ УНІВЕРСИТЕТ IМЕНІ І.Я. ГОРБАЧЕВСЬКОГО, \\ ТЕРНОПІЛЬ, УКРАЇНА \\ 2 - ІНСТИТУТ ЕКСПЕРИМЕНТАЛЬНОЇ ПАТОЛОГІЇ, ОНКОЛОГІЇ І РАДІОБІОЛОГІЇ ІМЕНІ Р.Є. КАВЕЦЬКОГО \\ НАН УКРАЇНИ, КИЇВ, УКРАЇНА \\ 3 - ІНСТИТУТ ЯДЕРНИХ ДОСЛІДЖЕНЬ НАН УКРАЇНИ, КИЇВ, УКРАЇНА
}

Вступ. Побічні ефекти протипухлинних лікарських засобів (найчастіше лейкопенія та нейтропенія) слугують основним лімітуючим фактором ефективного лікування. Наші попередні дослідження на здорових тваринах продемонстрували виражену ефективність при мелфалан-індукованій мієлосупресії, однак питання впливу будь яких додаткових чинників, які застосовуються у онкологічній практиці, на ріст та розвиток пухлини надзвичайно важливе.

Мета роботи: дослідити дію біосимілярів гранулоцитарного колонієстимулюючого фактора (Г-КСФ) та гранульованого вуглецевого ентеросорбента С2 при мелфалан-індукованій мієлосупресії у щурів з перевивною карциномою Герена.

Методи. Для індукування мієлосупресії у щурів з перевивною карциномою Герена мелфалан вводили у дозі 5,5 мг/кг. Для корекції викликаних змін використовували філграстим та аналог виробництва IЕПОР - рекомбінантний гранулоцитарний колонієстимулюючий фактор (р-ГКСФ). Для проведення ентеросорбції використано гранульований вуглецевий ентеросорбент С2 з питомою вагою

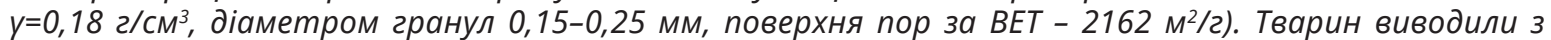
експерименту на 17-у добу після перещеплення пухлини (на 8-у добу після введення мелфалану).

Результати. Алкілуючий цитостатик викликав глибокі лейкопенію (падіння на 95,7\%), нейтропенію (зниження на 73,9\%) та тромбоцитопенію (падіння показника на 84,9\%) у дослідних тварин. Летальність склала 57\%. Застосування препаратів Г-КСФ та ентеросорбента С2 покращувало досліджувані показники, однак найбільш виражене покращення спостерігалося лише при введенні обох чинників разом. Введення обох чинників не зменшувало протипухлинну активність мелфалану як при моновведенні, так і в комбінації.

Висновки. Отримані нами результати свідчать про перспективи подальшого вивчення ефективності застосування комбінації ентеросорбції та гемостимулюючих цитокінів для пом'якшення побічних ефектів протипухлинної хіміотерапії та їх впровадження у клінічну практику.

КЛЮчОВІСЛОВА: мелфалан; карцинома Герена; щури; гранулоцитарний колонієстимулюючий фактор; ентеросорбція. 
Відомості про авторів:

Шевчук Оксана Олегівна - канд. мед. наук, доцент каф. фармакології з клінічною фармакологією, Тернопільський національний медичний університет імені І. Я. Горбачевського, Тернопіль, Україна. тодор Ігор Миколайович - д-р біол. наук, старший науковий співробітник Лабораторії механізмів медикаментозної резистентності, Інститут експериментальної патології, онкології і радіобіології імені Р.Є. Кавецького НАН України, Київ, Україна.

Лук'янова Наталія Юріївна - д-р біол. наук, старший науковий співробітник, зав. лабораторії механізмів медикаментозної резистентності, Інститут експериментальної патології, онкології і радіобіології імені Р. Є. Кавецького НАН України, Київ, Україна.

Родіонова Наталія Констянтинівна - канд. мед. наук, старший науковий співробітник відділу радіобіології та радіоекології, Інститут ядерних досліджень НАН України, Київ, Україна.

Ніколаєв Володимир Григорович - чл.-кор. НАН України, д-р мед. наук, професор, Заслужений діяч науки і техніки України, Лауреат Державної премії СРСР, зав. відділу засобів та методів сорбційної терапії, Інститут експериментальної патології, онкології і радіобіології імені Р. Є. Кавецького НАН України, Київ, Україна.

Чехун Василь Федорович - академік НАН України, д-р мед. наук, професор, Заслужений діяч науки і техніки України, Лауреат Державної преміїУкраїни в галузі науки і техніки, Інститут експериментальної патології, онкології і радіобіології імені Р.Є. Кавецького НАН України, Київ, Україна.

\section{Information about authors:}

Shevchuk 0.0. - MD, Ph.D., Associate Professor, Department of Pharmacology and Clinical Pharmacology, I. Horbachevsky Ternopil National Medical University, Ternopil, Ukraine.

ORCID 0000-0003-2473-6381, e-mail: shevchukoo@tdmu.edu.ua

Todor I.M. - Ph.D., DSc, R.E. Kavetsky Institute of Experimental Pathology, Oncology and Radiobiology of the National Academy of Sciences of Ukraine, Kyiv, Ukraine.

e-mail: todor@nas.gov.ua

Lukianova N.Yu. - MD, Ph.D., DSc., R.E. Kavetsky Institute of Experimental Pathology, Oncology and Radiobiology of the National Academy of Sciences of Ukraine, Kyiv, Ukraine.

Rodionova N.K. - MD, Ph.D., Institute for Nuclear Research of the National Academy of Sciences of Ukraine, Kyiv.

e-mail: oncom@onconet.kiev.ua

Nikolaev V.G. - MD, Ph.D., DSc, Professor, Corr. Member of the NAS of Ukraine, R.E. Kavetsky Institute of Experimental Pathology, Oncology and Radiobiology of the National Academy of Sciences of Ukraine, Kyiv. e-mail: aosiepor2@gmail.com

Chekhun V. F. - MD, Ph.D., DSc, Professor, Academician of the NAS of Ukraine, R.E. Kavetsky Institute of Experimental Pathology, Oncology and Radiobiology of the National Academy of Sciences of Ukraine, Kyiv. e-mail: chekhun@onconet.kiev.ua

\section{References}

1. Xing C, Liang B, Wu J, Yang Q, Hu G, Yan Y, et al. Prognostic significance of leukopenia during the induction phase in adult B cell acute lymphoblastic leukemia. Cancer Manag Res. 2018;10:625-35.

doi: 10.2147/CMAR.S158359

2. Al-Ansari S, Zecha JAEM, Barasch A, de Lange J, Rozema FR, Raber-Durlacher JE. Oral Mucositis Induced By Anticancer Therapies. Curr Oral Heal Reports. 2015 Dec 19;2(4):202-11.

doi: $10.1007 / s 40496-015-0069-4$

3. Turgeman O, Medical R, Blumenfeld Z, Medical R. Minimizing the doxorubicin-Induced gonadotoxicity by sphingosine-1-phosphate analogue FTY720 Minimizing the doxorubicin-Induced gonadotoxicity by. Am J Clin Exp Obs Gynecol. 2015;2(1):24-33.

4. Wang Y, Probin V, Zhou D. Cancer therapyinduced residual bone marrow injury-Mechanisms of induction and implication for therapy. Curr Cancer Ther Rev. 2006 Aug 1;2(3):271-9. doi: $10.2174 / 157339406777934717$

5. Gaducci A, Gargini A, Palla E, Fanucchi A, Genazzani AR. Neutropenic Enterocolitis in an Advanced Epithelial Ovarian Cancer Patient Treated with Paclitaxel/Platinum-based Chemotherapy: A Case Report and Review of the Literature. Anticancer Res. 2005;(25):2509-14.

Available from: https://pdfs.semanticscholar. org/e16b/eea03afd2a93686821 eff80a60696893301f. pdf

6. Lalami Y, KlasterskyJ. Impact of chemotherapyinduced neutropenia (CIN) and febrile neutropenia (FN) on cancer treatment outcomes: An overview about well-established and recently emerging clinical data. Crit Rev Oncol Hematol. 2017;120(June):163-79. doi: 10.1016/j.critrevonc.2017.11.005 
7. Denduluri N, Patt DA, Wang Y, Bhor M, Li X, Favret AM, et al. Dose delays, dose reductions, and relative dose intensity in patients with cancer who received adjuvant or neoadjuvant chemotherapy in community oncology practices. JNCCN J Natl Compr Cancer Netw. 2015 Nov;13(11):1383-93.

doi: 10.6004/jncen.2015.0166

8. Santolaya ME, Alvarez AM, Avilés CL, Becker A, Mosso C, O'Ryan $M$, et al. Admission clinical and laboratory factors associated with death in children with cancer during a febrile neutropenic episode. Pediatr Infect Dis J. 2007 Sep;26(9):794-8.

doi: 10.1097/INF.0b013e318124aa44

9. Bonadonna G, Moliterni A, Zambetti M, Daidone MG, Pilotti S, Gianni L, et al. 30 years' follow up of randomised studies of adjuvant CMF in operable breast cancer: cohort study. BMJ. 2005 Jan 29;330(7485):217.

doi: $10.1136 / \mathrm{bmj} .38314 .622095 .8 \mathrm{~F}$

10. Barnes G, Pathak A, Schwartzberg L. Pharmacoeconomics of Granulocyte Colony-Stimulating Factor: A Critical Review. Adv Ther. 2014 Jul 3;31(7):683-95.

doi: $10.1007 / \mathrm{s} 12325-014-0133-9$

11. Xie J, Cao J, Wang J, Zhang B, Zeng $X$, Zheng $H$, et al. Advantages with prophylactic PEG-rhG-CSF versus rhG-CSF in breast cancer patients receiving multiple cycles of myelosuppressive chemotherapy: an open-label, randomized, multicenter phase III study. Breast Cancer Res Treat. 2018 Apr 11;168(2):389-99.

Available from: http://link.springer.com/10.1007/ s10549-017-4609-6

12. Nikolaev VG. Sorption Therapy with the Use of Activated Carbons: Effects on Regeneration of Organs and Tissues. In: Hemoperfusion, Plasmaperfusion and Other Clinical Uses of General, Bio specific, Immuno and Leucocyte Adsorbents. WSPC; 2017. p. 221-43

doi: 10.1142/9789814749084_0007

13. Nikolaev VG, Sakhno LA, Snezhkova EA, Sarnatskaya VV, Yushko LA. Carbon adsorbents in oncology: Achievements and perspectives. Exp Oncol. 2011;33(1):2-8.

14. Nikolaev VG, Samsonov VA. Analysis of medical use of carbon adsorbents in China and additional possibilities in this field achieved in Ukraine. Artif Cells, Nanomedicine, Biotechnol. 2014;42(1):1-5.

\section{doi: $10.3109 / 21691401.2013 .856017$}

15. Muravskaya G V., Nikolaev VG, Sergeev VP, Krutilina NI, Bonatskaya L V., Klevtsov VN, et al. Enterosorption in Oncotherapy. Artif Cells, Blood Substitutes, Biotechnol. 1991;19(1):167-74.

doi: 10.3109/10731199109117823

16. Shevchuk OO, Posokhova KA, Todor IN, Lukianova NY, Nikolaev VG, Chekhun VF. Prevention of myelosuppression by combined treatment with enterosorbent and granulocyte colony-stimulating factor. Exp Oncol. 2015;37(2):135-8.

doi: 10.31768/2312-8852.2015.37(2):135-138

17. Shevchuk OO, Posokhova KA, Sidorenko AS, Bardakhivska KI, Maslenny VM, Yushko LA, et al. The influence of enterosorption on some haematological and biochemical indices of the normal rats after single injection of melphalan. Exp Oncol. 2014;36(2):94-100.

18. Liu W, Zhang C-C, Li K. Prognostic value of chemotherapy-induced leukopenia in small-cell lung cancer. Vol. 10, Cancer Biology \& Medicine. Chinese Anti-Cancer Association; 2013. p. 92-8.

Available from: http://www.ncbi.nlm.nih.gov/ pubmed/23882424

19. Held TK, Gundert-Remy U. Pharmacodynamic Effects of Haematopoietic Cytokines: The View of a Clinical Oncologist. Basic Clin Pharmacol Toxicol. 2010 Mar 1;106(3):210-4.

doi: $10.1111 /$ j.1742-7843.2009.00514.x

20. American Society of Clinical Oncology. Recommendations for the use of hematopoietic colony-stimulating factors: evidence-based, clinical practice guidelines.J Clin Oncol. 1994 Nov;12(11):2471508.

doi: 10.1200/JCO.1994.12.11.2471

21. Lyman GH, Allcott K, Garcia J, Stryker S, Li Y, Reiner MT, et al. The effectiveness and safety of same-day versus next-day administration of longacting granulocyte colony-stimulating factors for the prophylaxis of chemotherapy-induced neutropenia: a systematic review. Support Care Cancer. 2017 Aug 8;25(8):2619-29.

doi: $10.1007 / \mathrm{s} 00520-017-3703-y$

22. Vial T, Descotes J. Clinical Toxicity of Cytokines Used as Haemopoietic Growth Factors. Drug Saf. 1995 Dec;13(6):371-406.

doi: 10.2165/00002018-199513060-00006

23. Gavioli E, Abrams M. Prevention of granulocyte-colony stimulating factor (G-CSF) induced bone pain using double histamine blockade. Support Care Cancer. 2017 Mar 5;25(3):817-22.

doi: 10.1007/s00520-016-3465-y

24. Khoury H, Adkins D, Brown R, Vij R, Westervelt $P$, Trinkaus $K$, et al. Adverse side-effects associated with G-CSF in patients with chronic myeloid leukemia undergoing allogeneic peripheral blood stem cell transplantation. Bone Marrow Transplant. 2000 Jun 5;25(11):1197-201.

doi: $10.1038 /$ sj.bmt.1702423

25. Mehta HM, Malandra M, Corey SJ. G-CSF and GM-CSF in Neutropenia. J Immunol. 2015 Aug 15;195(4):1341-9.

doi: 10.4049/jimmunol.1500861

26. Heslet L, Bay C, Nepper-Christensen S. Acute radiation syndrome (ARS) - treatment of the reduced host defense. Int J Gen Med. 2012;5:105-15.

doi: 10.2147/IJGM.S22177

27. Sarnatskaya VV, Sakhno L, Paziuk LM, Yushko LA, Rodionova NK, Maslenniy VN, et al. Highly activated carbon enterosorbent mediates the suppression of paraneoplastic syndrome associated with Lewis lung carcinoma in mice. Exp Oncol. 2018 Mar;40(1):33-41.

doi: $10.31768 / 2312-8852.2018 .40(1): 33-41$

28. Mikhalovsky SV, Sandeman SR, Howell CA, Phillips GJ, Nikolaev VG. Biomedical Applications of 
Carbon Adsorbents. In: Novel Carbon Adsorbents. Elsevier; 2012. p. 639-69.

doi: 10.1016/B978-0-08-097744-7.00021-1

29. Ponomariova OV, Pivniuk VM, Nosko MM, Sakhno LO, Dekhtiar TV, Nikolaev VG, et al. Prophylaxis with carbon enterosorbent of acute and delayed emetogenic toxicity of chemotherapy treatment in oncologic patients. Onkologia. 2008;10(3):370-3 [in Ukrainian].

Available from: http://dspace.nbuv.gov.ua/ handle/123456789/11944
30. Sakhno LA, Yurchenko OV, Maslenniy VN, Bardakhivskaya KI, Nikolaeva VV, Ivanyuk AA, et al. Enterosorption as a method to decrease the systemic toxicity of cisplatin. Exp Oncol. 2013;35(1):45-52.

Available from: http://dspace.nbuv.gov.ua/ handle/123456789/13911

Received 01 April 2019; revised 29 April 2019; accepted 10 May 2019.

This is an open access article distributed under the Creative Commons Attribution License, which permits unrestricted use, distribution, and reproduction in any medium, provided the original work is properly cited. 